\title{
Evaluation of Patients under Investigation for MERS-CoV Infection, United States, January 2013-October 2014
}

\section{Eileen Schneider, Christina Chommanard, Jessica Rudd, Brett Whitaker, Luis Lowe, Susan I. Gerber}

Middle East respiratory syndrome (MERS) cases continue to be reported from the Middle East. Evaluation and testing of patients under investigation (PUIs) for MERS are recommended. In 2013-2014, two imported cases were detected among 490 US PUls. Continued awareness is needed for early case detection and implementation of infection control measures.

$\mathrm{M}$ iddle East respiratory syndrome coronavirus (MERS-CoV) infection was first reported in September 2012 in a patient with fatal pneumonia in Saudi Arabia (1). Subsequent investigation showed that earlier MERSCoV infection had occurred in Jordan in April 2012 among a cluster of patients with pneumonia $(2,3)$. As of February 5, 2015, the World Health Organization had reported 971 laboratory-confirmed cases worldwide and at least 356 related deaths (4). All known reported cases have been linked directly or indirectly to the Middle East region; most have been reported by Saudi Arabia and the United Arab Emirates. Typically, the initial symptoms for MERS patients seeking medical care are fever, chills, cough, shortness of breath, and myalgia. These symptoms often progress to severe lower respiratory tract infection, which may require mechanical ventilation and intensive care $(5,6)$. Several asymptomatic or mild MERS cases have been reported (7), particularly in healthy young adults. Little is known about transmission routes, virus shedding, risk factors, and animal reservoirs, although bats and camels have been implicated in transmission and as reservoirs $(8,9)$. Clusters of human-to-human transmission have been associated with household and health care settings $(2,3,5)$.

Using World Health Organization guidelines and definitions (4), CDC developed guidance for evaluating a patient under investigation (PUI) for MERS-CoV infection, collecting specimens, conducting laboratory testing, and managing infection control (http://www.cdc.gov/coronavirus/mers/index.html). The PUI guidance was created to assist health care providers determine which patients should

Author affiliation: Centers for Disease Control and Prevention,

Atlanta, Georgia, USA

DOI: http://dx.doi.org/10.3201/eid2107.141888 be considered for MERS-CoV evaluation and testing. To inform state and local health departments of the basic demographic and clinical characteristics of PUIs and on assay use, we summarized the descriptive analysis of PUIs in the United States.

\section{The Study}

In October 2012, CDC developed real-time reverse transcription PCR (rRT-PCR) assays for detection of MERSCoV (10). CDC initially performed the testing, but on June 5, 2013, a Food and Drug Administration-issued Emergency Use Authorization allowed for assay deployment in a kit to laboratories through the Laboratory Response Network. As of March 12, 2015, a total of 47 states and the District of Columbia had MERS-CoV testing capability. The assay kit is intended for detection of MERS-CoV RNA in respiratory, serum, and stool samples. CDC also developed serologic tests for detecting MERS-CoV antibodies; these tests have been used by CDC since the summer of 2013. Because MERS-CoV is an emerging pathogen, CDC guidelines and guidance regarding PUI characteristics are periodically updated as new MERS-CoV information and risk factors are identified. $\mathrm{CDC}$ recommends evaluating and testing PUIs for MERS-CoV and for other common respiratory pathogens.

On January 1, 2013, CDC began collecting data on PUIs for MERS-CoV infection. Health care providers for persons suspected of having MERS were to contact their state or local health department for consultation and to arrange for MERS-CoV testing, if indicated. PUIs were reported to CDC through state and local health departments by using the single-page PUI short form, which contains no personal identifiers (11). Since its implementation, the short form has been revised 3 times to reflect modifications to the PUI guidance. The short form collects information on basic demographic data, symptoms, disease severity, hospitalization, travel history, risk factors, and laboratory test results at the time of MERS-CoV testing. Follow-up data collection on missing information was not routinely performed. At least 370 (76\%) PUIs met the guidance characteristics for PUI for MERS. The remaining 120 (24\%) PUIs had incomplete clinical or travel data; the most common missing information was pneumonia data for persons with respiratory symptoms and a recent travel history. The short form was sent electronically to CDC by secure fax or email. Data collected on the short form was entered into a 
CDC database by using Microsoft Access (Microsoft Corporation, Redmond, WA, USA). SAS version 9.3 (SAS Institute, Cary, NC, USA) was used for data analysis.

During January 1, 2013-October 31, 2014, a total of 490 PUIs were reported to CDC from 45 states and the District of Columbia (Figures 1, 2; Table 1). Of the 490 PUIs, 381 (78\%) reported traveling from the Arabian Peninsula or neighboring countries to the United States within 14 days before illness onset (Table 2). A total of 113 (23\%) PUIs also reported having close contact with a recently ill traveler from the Arabian Peninsula or neighboring countries within 14 days of symptom onset; the most common contacts were with persons from Saudi Arabia (55/113 [49\%]), United Arab Emirates (10/113 [9\%]), and Qatar (9/113 [8\%]). Non-US residents accounted for $113(23 \%)$ of the PUIs.

The most commonly reported symptoms were cough, fever, and shortness of breath (Table 1). A total of 292 (60\%) PUIs were hospitalized, of whom 112 (38\%) were admitted to the intensive care unit and $61(21 \%)$ required mechanical ventilation. The most commonly reported underlying conditions among PUIs were immunosuppression and diabetes. Eleven (2\%) PUIs died.

In total, 488 PUIs tested negative for MERS-CoV by rRT-PCR, serologic assay, or both. In May 2014, two PUIs tested positive for MERS-CoV by serologic assay and rRT-PCR in serum and respiratory samples, including lower respiratory tract specimens. These 2 patients were health care providers in whom respiratory symptoms had developed within 14 days of travel from Saudi Arabia; both cases were identified as imported MERS $(12,13)$. Neither patient required mechanical ventilation.

The most commonly detected pathogens among the 490 PUIs were influenza A virus and rhinovirus/enterovirus;

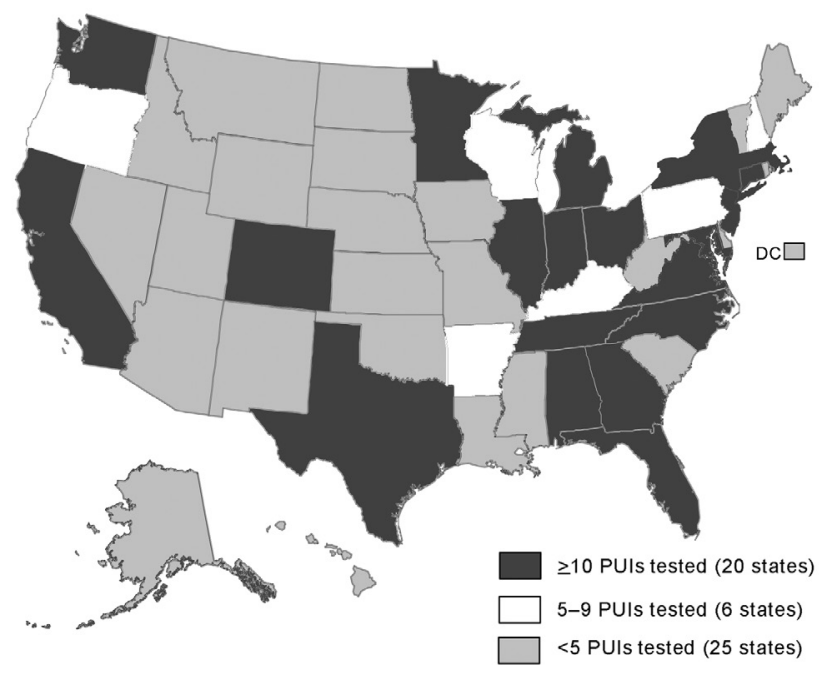

Figure 1. Number of PUls tested for MERS-CoV $(\mathrm{N}=490)$, by state, United States, January 1, 2013-October 31, 2014. DC, District of Columbia; PUIs, patients under investigation.

however, for 359 PUIs (73\%), other pathogen testing was not performed or detected pathogens were not reported (Table 1). Timely reporting of PUIs to CDC may have influenced reporting of pending non-MERS-CoV etiologic pathogen test results.

\section{Conclusions}

Currently in the United States, the preferred method for detecting MERS in PUIs with recent symptom onset is to test lower respiratory, naso-oropharyngeal, and serum specimens by using the CDC rRT-PCR assay. For PUIs in whom symptom onset occurred $\geq 2$ weeks before specimen collection, testing using the CDC MERS-CoV

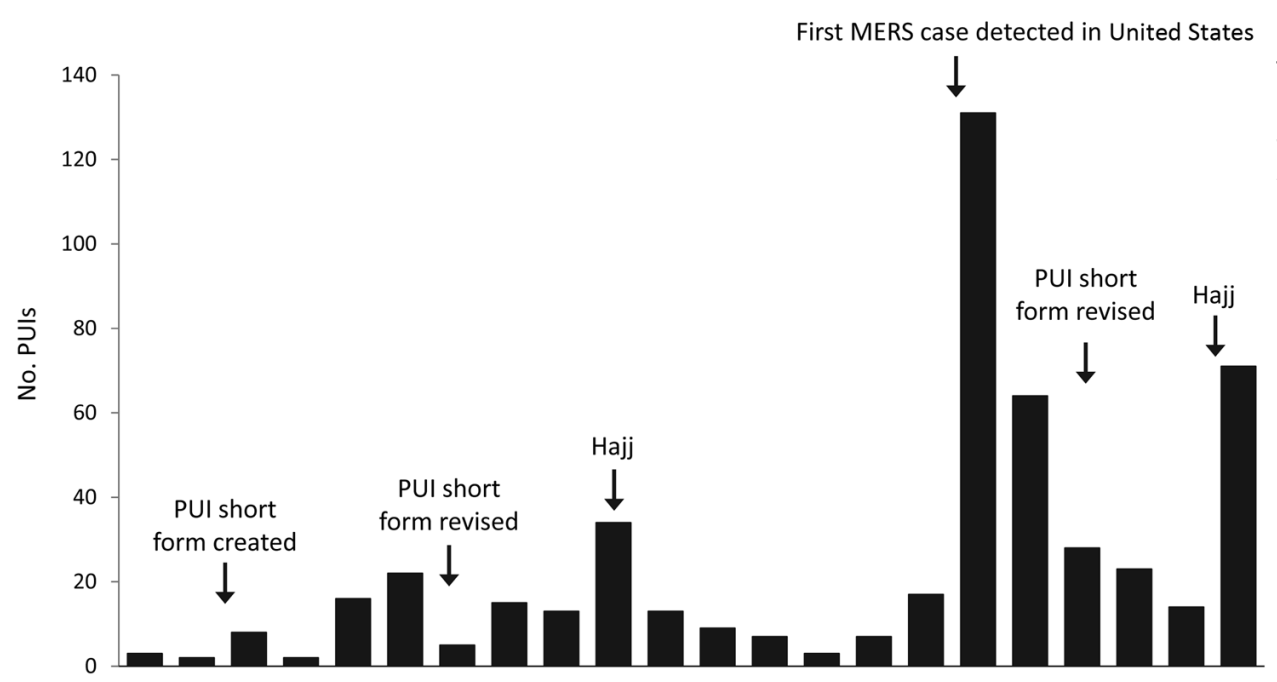

Figure 2. Number of PUls tested for MERS-CoV $(N=490)$, by month reported, United States, January 1, 2013-October 31, 2014. PUls, patients under investigation.

Jan Feb Mar Apr May Jun Jul Aug Sep Oct Nov Dec Jan Feb Mar Apr May Jun Jul Aug Sep Oct 
Table 1. Characteristics of 490 PUls for MERS-CoV, United States, January 1, 2013-October 31, 2014*

\begin{tabular}{|c|c|}
\hline Characteristic & Value \\
\hline Sex, M/F & $296(60.4) / 186(38.0)$ \\
\hline Median age, y (range) & $48(0.3-89)$ \\
\hline \multicolumn{2}{|l|}{ Symptom } \\
\hline Cough & 393(80.2) \\
\hline Fever & 388 (79.2) \\
\hline Shortness of breath & 220 (44.9) \\
\hline Chills $†$ & $153(35.1)$ \\
\hline Myalgia† & $140(32.1)$ \\
\hline Sore throat & $134(27.4)$ \\
\hline Headache† & $106(24.3)$ \\
\hline Diarrhea† & $58(13.3)$ \\
\hline Abdominal pain $\dagger$ & $34(7.8)$ \\
\hline Hospitalized & $292(59.6)$ \\
\hline Intensive care unit & $112(38.4)$ \\
\hline Mechanical ventilation & $61(20.9)$ \\
\hline \multicolumn{2}{|l|}{ Clinical finding } \\
\hline Pneumoniał & $236(48.2)$ \\
\hline Acute respiratory distress syndrome $\ddagger$ & $48(9.8)$ \\
\hline Renal failure & $22(4.5)$ \\
\hline Died & $11(2.2)$ \\
\hline \multicolumn{2}{|l|}{ Underlying condition† } \\
\hline Immunosuppression & $55(12.6)$ \\
\hline Diabetes & $40(9.2)$ \\
\hline Hypertension & $27(6.2)$ \\
\hline Cardiac disease & $23(5.3)$ \\
\hline Asthma & $20(4.6)$ \\
\hline Chronic pulmonary disease & $11(2.5)$ \\
\hline Hyperlipidemia & $9(2.1)$ \\
\hline Pregnant & $8(1.8)$ \\
\hline Renal disease & $7(1.6)$ \\
\hline Other & $12(2.8)$ \\
\hline \multicolumn{2}{|l|}{ Specific job classification $\dagger$} \\
\hline Health care worker & $35(8.0)$ \\
\hline US military & $9(2.1)$ \\
\hline \multicolumn{2}{|l|}{ MERS-CoV rRT-PCR testing } \\
\hline \multicolumn{2}{|l|}{ Specimen type } \\
\hline Upper respiratory & $414(84.5)$ \\
\hline Lower respiratory & $242(49.4)$ \\
\hline Serum & $235(48)$ \\
\hline Stool & $40(8.2)$ \\
\hline MERS-CoV positive & $2(0.4)$ \\
\hline \multicolumn{2}{|l|}{ Serologic testing for MERS-CoV } \\
\hline Tested & $67(13.7)$ \\
\hline MERS-CoV positive & $2(0.4)$ \\
\hline \multicolumn{2}{|l|}{ Other pathogens detected§ } \\
\hline Influenza A virus & $41(8.4)$ \\
\hline Rhinovirus/enterovirus & $37(7.6)$ \\
\hline Influenza B virus & $13(2.7)$ \\
\hline Streptococcus pneumoniae & $11(2.2)$ \\
\hline Human metapneumovirus & $6(1.2)$ \\
\hline Adenovirus & $5(1.0)$ \\
\hline Coronavirus & $4(0.8)$ \\
\hline Respiratory syncytial virus & $4(0.8)$ \\
\hline Parainfluenzavirus & $3(0.6)$ \\
\hline Chlamydophila pneumoniae & $2(0.4)$ \\
\hline Legionella pneumoniae & $2(0.4)$ \\
\hline Other & $16(3.3)$ \\
\hline \multicolumn{2}{|c|}{$\begin{array}{l}\text { *Data are no. (\%) unless otherwise specified. MERS-CoV, Middle East } \\
\text { respiratory syndrome coronavirus; PUI, patient under investigation; rRT- } \\
\text { PCR, real-time reverse transcription PCR. } \\
\text { tIncluded only in } 2 \text { most recent versions of PUI short form }(\mathrm{N}=436) \text {. } \\
\text { fForty-one PUls had pneumonia and acute respiratory distress syndrome. } \\
\text { §Etiologic pathogen not reported for } 359(73 \%) \text { PUIs; } \geq 1 \text { pathogen } \\
\text { identified for some PUls. }\end{array}$} \\
\hline
\end{tabular}

Table 2. Countries from which 381 PUIs for MERS-CoV infection had traveled within 14 days of symptom onset, United States January 1, 2013-October 31, 2014*

\begin{tabular}{lc}
\hline Country & No. (\%) \\
\hline Saudi Arabia & $189(49.6)$ \\
United Arab Emirates & $60(15.7)$ \\
Israel & $45(11.8)$ \\
Jordan & $34(8.9)$ \\
Qatar & $27(7.1)$ \\
Kuwait & $22(5.8)$ \\
Egypt & $12(3.1)$ \\
Bahrain & $10(2.6)$ \\
Oman & $9(2.4)$ \\
Iran & $8(2.1)$ \\
Iraq & $8(2.1)$ \\
Lebanon & $8(2.1)$ \\
Turkey & $8(2.1)$ \\
Pakistan & $6(1.6)$ \\
Palestinian Territories & $6(1.6)$ \\
Yemen & $6(1.6)$ \\
Other† & $13(3.4)$ \\
\hline *atients may have been in >1 country. PUI, patient under investigation. \\
†Azerbaijan (1); Afghanistan (2); Bangladesh (1); Greece (1); India (2); \\
Indonesia (2); Kenya (1); Morocco (1); Somalia (1); Syria (1).
\end{tabular}

serologic assay on a single serum specimen is recommended. CDC also recommends testing for common respiratory pathogens (e.g., influenza virus), but identification of a respiratory pathogen should not preclude MERS-CoV testing (14). The PUI guidance serves to help health care providers and state health departments identify patients for evaluation and testing for MERS$\mathrm{CoV}$ infection; however, because we are still learning about the natural history of MERS-CoV, it is reasonable to consider testing for MERS-CoV even when some PUI characteristics are not present, especially in the presence of strong clinical or epidemiologic judgment for MERS-CoV. During the evaluation process for MERS$\mathrm{CoV}$ infection, appropriate infection control measures should be instituted as soon as possible for hospitalized and nonhospitalized PUIs (15).

The 2 US cases of imported MERS were detected in health care providers from Saudi Arabia. These cases prompted a CDC guidance update recommending evaluation and testing of persons with less severe respiratory illness who had strong epidemiologic risk factors, particularly heath care exposure, for MERS-CoV infection. Occupation, recent travel history, recent visit to a health care facility, and contact will ill persons should be determined when evaluating persons with respiratory illness. As testing increases, especially serologic testing, additional MERS cases, including mildly symptomatic cases and cases among younger persons are being identified. These cases highlight the range of severity of MERS-CoV infection and the need to consider testing persons with a compatible travel history who may not match the clinical profile of the initially described case-patients. CDC plans to revise MERS-CoV guidance as needed. 


\section{Acknowledgment}

We thank the state and local health departments, healthcare providers, CDC Emergency Operations Center, and CDC MERS Domestic Response Team for all of their hard work on MERS$\mathrm{CoV}$, especially in evaluating, testing, and reporting PUIs.

Dr. Schneider is a senior medical epidemiologist with the Division of Viral Diseases, CDC. Her current research interests include respiratory viruses.

\section{References}

1. Zaki AM, van Boheemen S, Bestebroer TM, Osterhaus ADME, Fouchier RAM. Isolation of a novel coronavirus from a man with pneumonia in Saudi Arabia. N Engl J Med. 2012;367:1814-20. http://dx.doi.org/10.1056/NEJMoa1211721

2. Milne-Price S, Miazgowicz KL, Munster VJ. The emergence of the Middle East respiratory syndrome coronavirus. Pathog Dis. 2014;71:121-36. http://dx.doi.org/10.1111/2049-632X.12166

3. Raj VS, Osterhaus A. DME, Fouchier R AM, Haagmans BL. MERS: emergence of a novel human coronavirus. Curr Opin Virol. 2014;5:58-62. http://dx.doi.org/10.1016/j.coviro.2014.01.010

4. World Health Organization. Middle East respiratory syndrome coronavirus (MERS-CoV): summary of current situation, literature update and risk assessment - as of 5 February 2015 [cited 2015 Mar 10]. http://www.who.int/csr/disease/coronavirus_infections/ mers-5-february-2015.pdf?ua $=1$

5. Assiri A, Al-Tawfiq JA, Al-Rabeeah AA, Al-Rabiah FA, Al-Hajjar S, Al-Barrak A, et al. Epidemiological, demographic, and clinical characteristics of 47 cases of Middle East respiratory syndrome coronavirus disease from Saudi Arabia: a descriptive study. Lancet Infect Dis. 2013;13:752-61. http://dx.doi.org/ 10.1016/S1473-3099(13)70204-4

6. Drosten C, Seilmaier M, Corman VM, Hartmann W, Scheible G, Sack S, et al. Clinical features and virological analysis of a case of Middle East respiratory syndrome coronavirus infection. Lancet Infect Dis. 2013;13:745-51. http://dx.doi.org/10.1016/S1473-3099 (13)70154-3

7. Omrani AS, Matin MA, Haddad Q, Al-Nakhli D, Memish ZA, Albarrak AM. A family cluster of Middle East respiratory syndrome coronavirus infections related to a likely unrecognized asymptomatic or mild case. Int J Infect Dis. 2013;17:e668-72. http://dx.doi.org/10.1016/j.ijid.2013.07.001
8. Memish ZA, Mishra N, Olival KJ, Fagbo SF, Kapoor V, Epstein JH, et al. Middle East respiratory syndrome coronavirus in bats, Saudi Arabia. Emerg Infect Dis. 2013;19:1819-23. http://dx.doi.org/10.3201/eid1911.131172

9. Reusken CB, Farag EA, Jonges M, Godeke GJ, El-Sayed AM, Pas SD, et al. Middle East respiratory syndrome coronavirus (MERS-CoV) RNA and neutralising antibodies in milk collected according to local customs from dromedary camels, Qatar, April 2014. Euro Surveill. 2014;19:20829.

10. Lu X, Whitaker B, Sakthivel SKK, Kamili S, Rose LE, Lowe L, et al. Real-time transcription-PCR assay panel for Middle East respiratory syndrome coronavirus. J Clin Microbiol. 2014;52: 67-75. http://dx.doi.org/10.1128/JCM.02533-13

11. Centers for Disease Control and Prevention. Middle East respiratory syndrome (MERS). Data collection [cited 2015 Mar 10]. http://www.cdc.gov/coronavirus/mers/data-collection.html

12. Bialek SR, Allen D, Alvarado-Ramy F, Arthur R, Balajee A, Bell D, et al. First confirmed cases of Middle East respiratory syndrome coronavirus (MERS-CoV) infection in the United States, updated information on the epidemiology of MERS-CoV infection, and guidance for the public, clinicians, and public health authorities-May 2014. MMWR Morb Mortal Wkly Rep. 2014; 63:431-6.

13. Kapoor M, Pringle K, Kumar A, Dearth S, Liu L, Lovchik J, et al. Clinical and laboratory findings of the first imported case of Middle East respiratory syndrome coronavirus (MERS-CoV) in the United States. Clin Infect Dis. 2014;59:1511-8. http://dx.doi.org/10.1093/ $\mathrm{cid} / \mathrm{ciu} 635$

14. Centers for Disease Control and Prevention. Interim guidelines for collecting, handling, and testing clinical specimens from patients under investigation (PUIs) for Middle East respiratory syndrome coronavirus (MERS-CoV)—version 2 [cited 2015 Mar 10] http://www.cdc.gov/coronavirus/mers/ guidelines-clinical-specimens.html

15. Centers for Disease Control and Prevention. Interim infection prevention and control recommendations for hospitalized patients with Middle East respiratory syndrome coronavirus (MERS-CoV) [cited 2015 Mar 10]. http://www.cdc.gov/coronavirus/mers/ infection-prevention-control.html

Address for correspondence: Eileen Schneider, Centers for Disease Control and Prevention, 1600 Clifton Rd NE, Mailstop A34, Atlanta, GA, 30329-4027, USA; email: ees2@cdc.gov

\section{EID Podcast: Carbapenem-Resistant Enterobacteriaceae}
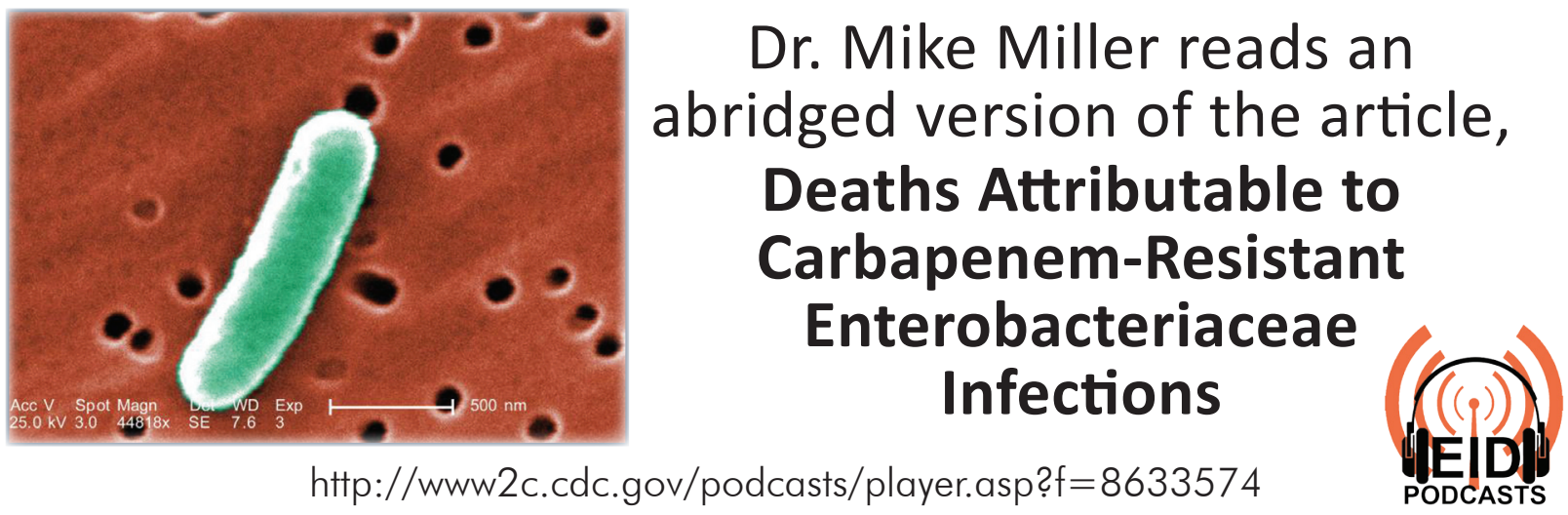

http://www2c.cdc.gov/podcasts/player.asp?f $=8633574$ 